\title{
Forsøgsstation for urbanisering
}

I anledning af 20-året for Svend Åge Madsens Tugt og utugt i mellemtiden og metropoliseringen af Århus

\section{Marianne Ping Huang.}

At indskrive Danmarks næststørste by mellem metropolerne Paris, Wien, Berlin og Barcelona tager sig ud som en af de vittigheder, Århus er mere kendt for end for sin karakter af storby. Paris, Wien, Berlin og Barcelona har hver med sin modernitets- og moderniseringshistorie formet urbanitetsanalysen i arkitektur- og litteraturhistorien. Således er 'Paris i det 19. århundrede' og 'Wien omkring århundredskiftet' samlebetegnelser for hele begrebskomplekser, for urbane kulturtilstande og deres analytik. Både det 19. århundredes Paris, som vi kender det fra Balzac, Baudelaire og Walter Benjamin, og århundredeskiftets Wien hos Robert Musil, Arthur Schnitzler og Peter Altenberg er kulturelle krydsfelter, der skiftevis lader sig bestemme kosmogonisk - som begyndelser til den ny verden eller den ny tid, der skulle være den moderne - og apokalyptisk, med wienerne Karl Kraus' og Hermann Brochs ord om Donaustaden, som "forsøgsstation for verdensundergangen" og en "munter apokalypse".

Sådan skulle man ikke tro, at en større dansk provinsby lader sig beskrive- - og alligevel er det netop sådan Svend Åge Madsen fremskriver Århus som sit romanunivers i Tugt og utugt i mellemtiden. Romanen bliver måske netop $i$ kraft af sin bybeskrivelse en kernetekst i forfatterskabet, fordi Svend Åge Madsen her - på en gang loyal og karikerende i sine beskrivelser af de moderne metropoler - kalkererer en metropolisering af Århus frem. Tugt og 
utugt $i$ mellemtiden er Gründer-tiden hos Madsen, den store roman fra 1976 udgør en matrise, som de senere romaner, der nær sagt alle er 'Århus-romaner', formes i. Det gælder romanen At fortælle menneskene fra 1989, hvor vi genfinder personer, eller i det mindste Madsens karakteristisk skæve personnavne, fra Tugt og utugt $i$ mellemtiden, og det gælder Madsens seneste roman, Syv aldres galskab, fra 1994, hvor byens topografi og beskrive-topoi spiller en ikke uvæsentlig rolle i opbygningen af romanens slægts- og tidsmaskine. Således modtager den historiske hovedperson Hans Skonning, klokker og bogtrykker $\mathrm{i}$ Århus, fra romanens begyndelse sine guddommelige åbenbaringer eller visioner af fremtidens Århus fra Domkirketårnet - den klassiske topos for overblik i by-beskrivelsen, som Madsen i Tugt og utugt i mellemtiden knytter til det andet markante tåmn i Århus' skyline, Rådhusets.

Tugt og utugt i mellemtiden er også en kernetekst, fordi Madsen hér lader sin protagonist, Ludvig Alster, praktisere det kendte madsenske forhold mellem fortælling og verden, som beskrives så godt af fortælleren i At fortælle menneskene: „Måske foreligger verden, før vi træder ind $i$ den. Men som en drøm kan den kun fastholdes ved at vi fortæller den. Og ved at fortælle den former vi den efter bedste evne og giver den mening ${ }^{\prime \prime}{ }^{1}$ Dette nominalistiske fiktionsforhold balanceres imidlertid i Madsens Århus-romaner af byens topografi, som nok er forvrænget eller groteskgjort, ${ }^{2}$ men hvis forvrængning forudsætter, at den århusianske by-verden omfatter stedernes genkendelighed og de genkendelige topoi fra klassiske metropol-romaner. Når det gælder forholdet mellem fiktionalisering og metropolisering af romanuniverset, er det tillige muligt, at der i Tugt og utugt $i$ mellemtiden grundlægges såvel en kosmogoni som en eskatologi for fortællingens udfoldelser. Fortællingen om Århus anno 1975 anskues gennem fortælleren Ato Vari fra fremtiden, den udfolder sig i romantitlens 'mellemtid', men ligger også - som jeg skal komme tilbage til - indfældet mellem to sluser og to atopier eller intetsteder. Romanens univers er et energisk rum mellem verdens skabelse og undergang: Fröhliche Kosmogonie, fröhliche Apokalypse.

\section{Detaljernes evidens}

Hvad der imidlertid også springer i øjnene tyve år efter romanens udgivelse er dens forankring i sin tid, hvilket viser sig ikke alene i de objekter, som repræsenteres, men også i den sociale typologisering af byens masse, som er en del af romanens anliggende. Tugt og utugt $\mathrm{i}$ mellemtiden er så at sige på tyve år blevet historisk.

Det Århus, som fremstilles i romanen, er uomtvisteligt Århus anno 1975. Forankringen synes for en stor del at være diskursiv, dvs. forbundet med en for sin tid karakteristisk typologisering og social utopi, og således også forbundet med romanens rumlighed eller med detaljer i metropoliseringen, men denne referentialitet ligger uden for det bevidste arbejde med romanens rum, fx. med bybeskrivelsens topoi. At konstatere dette forhold er ikke i sig selv interessant, det siger i alle tilfælde ikke med nødvendighed noget om romanen som litterært værk; men hvis - som jeg i det følgende vil lade den norske forfatter Jan Kjærstad plædere for -Svend Åge Madsen i sin komposition og fremstilling ikke er en egentlig repræsenterende eller beskrivende forfatter, så bliver den diskursive referentialitet og detaljering alligevel interessant som en utilsigtet (men meget iøjnefaldende) ornamentering i romanens rum (se note 4 ).

Ofte er det Madsens ekspliciterede fortællerinstanser eller hans temporale paradokser, der fremhæves og analyseres som forfatterskabets og den enkelte romans karakteristikum. Kunne man imidlertid læse Tugt og utugt $i$ mellemtiden også som en roman om byen, dvs. om byens rumlighed, dens topografiske genkendelighed og rumlige praksis, ville forholdet mellem fortælling og verdensskabelse få et andet perspektiv, knyttet til disse evidenser, der er iøjnefaldende på en anderledes 'irriterende' måde end fx. fortællerinstansens vekselvise kommen til syne og gøren sig usynlig.

Byen i Tugt og utugt i mellemtiden er ikke (selvom det her indledningsvis er antydet og selvom romanens by-fremstilling er hæftet til topoi fra det 19. århundredes by-romaner) en panoramisk genskrivning af et urbant rum. For er Madsens Århus punktuelt 
en genkendelig topografi (og en historisk genkendelig diskursiv typologi), er byen først og fremmest en topologisk og lingvistisk konstruktion, som beror på sit ordmateriale og sine nøjagtigt udvalgte detaljer og teknikker, herunder tilsynekomsten af byens bygninger, monumenter, pladser og gader ikke bare på de rigtige steder i byen, men også på de rigtige steder i romanen.

Forskellen mellem Madsens fremstilling og brug af byens univers og den status byen har hos fx. Balzac kan begrundes i en formalisering som dén, Jan Kjærstad beskriver Madsens forfatterskab ved. Når Kjærstads omtale af Svend Åge Madsen er interessant, er det også, fordi Kjærstads Oslo-romaner, Homo Falsus (1986) og. Rand (1989), har store ligheder med balancen mellem fiktionalisering og fremstillingen af et by-rum hos Madsen. Jan Kjærstad omtaler Madsen som én af de "danske muslimer", han i essayet „Dansk 70-tall som missing link"3 beskriver således: "Som ekte muslimer har disse forfattere sans for ornamenter, for dekorasjoner, for mønstre". Når det gælder byrummet i Tugt og utugt $i$ mellemtiden dannes det trods sin genkendelighed snarere $\mathrm{i}$ det, Kjærstad kalder en matrise-form - en tredimensionel narrationsmaskine til fordeling af plot og ornamentale detaljer ${ }^{4}$ - end på panoramaets rundhorisont. Kjærstad skriver om Tugt og utugt i mellemtiden:

Det som slår mig mest ved denne roman, er hvor legende let forfatteren bygger et univers op, og hvordan det hele tiden afsløres at det konstrueres, ikke mindst gennem en utilsløret brug af eksisterende genrer: lidt sci-fi, lidt krimi, lidt kærlighed. De kendte genre-elementer bliver ustandseligt manipuleret, og det på en måde som tvinger læseren ind $\mathrm{i}$ rollen som medkonstruktør. Jeg oplever denne og flere af Madsens andre bøger som udgjort af moduler, der kan flyttes og hele tiden danne forskellige rum for de personer som skrives ind i teksten - forfatteren og læseren medregnet. ${ }^{5}$

Kjærstad giver her en parafrase af Madsens fiktions- og kompositionsspil, med 'de flytbare moduler' og deres variede rumdannelse, som kan minde om fx. arkitekten Aldo Rossis neo-rationalistiske rekonstruktioner af by-rum gennem kombinationer af bygningsmoduler. Den varierede rumdannelse har også sine lig- heder med et senere begreb i Kjærstads litteraturkritik, nemlig hvor han i artiklen "Menneskets felt" (Kritik 111) om en anden dansk by`roman, Peer Hultbergs Byen og verden (1992), bruger begrebet feltroman.

Mens matrisen er kompositionsprincippet bag et spind af informative, evidente og transcendentale detaljer (se note 4), priviligerer 'feltet' både det stedslige og dets virtuelle ornamentik. Således forbinder Kjærstad 'feltet' med begrebet genius loci, 'stedets ånd' eller prædisposition for at blive by. Kjærstad redefinerer begrebet til et steds prædisposition for at blive fortalt og billedgør denne disposition gennem eksemplet „en gammel slagmark [...] skueplads for en afgørende historisk begivenhed, et sted som på en kompliceret måde - og det fornemmer man ved at gå der - er svanger med fortælling." Stedet er altså narrativt, eller snarere ornamentalt i Kjærstads betydning. Det beskrives ikke primært gennem sine dimensioner, men ved sine associationer, ligesom feltets dynamik eller rumlige praksis ikke udgøres af den enkelte fortælling, men af fortællingernes processuelle samordning. Denne samordning kan være eksperimenterende, mens den enkelte fortælling eller detalje ofte har en velkendt, traditionel form.

Man kunne i Tugt og utugt i mellemtiden tale om to stabile, dimensionerede rum og ét rum skabt af rumlig praksis. De to første ville da være 1) kompositionens eller narrationens rum og 2) byen som sted eller plan, mens det sidste ville være de interferenser eller den anden orden, som Madsen installerer ved at samordne sin romans storkomposition med Århus anno 1975 gennem mindre narrative greb, gennem eksponeringer af detaljer ved byens plan og topoi i bybeskrivelsen.

Intetsteds, sluse, mellemrum

Madsens Tugt og utugt i mellemtiden begynder intetsteds og uden for Århus, nemlig i Horsens Tugthus, hvor Ludvig Alster har siddet $\mathrm{i}$ tolv år, uretfærdigt dømt for mord. Under indespærringen har hans omverdens- og jeg-orientering fortonet sig, og Alsters evne til at skelne er reduceret. Han befinder sig i „denne evige 
støjdynge og dette sammenpressede rum". Horsens Tugthus er atopisk, fordi det er uden disposition for at (lade fx. Alster) udfolde en sproglig og rumlig praksis. Horsens Tugthus bliver i romanen et sted, som er uden prædisposition for at blive fortalt, det er et 'tugtet' rum.

Alster er på en måde sanseløs eller bedøvet, hvilket både skyldes fængslets tuigt, men også en disposition hos Alster. Sanseløs af kærlighed til Irmelin Deyk bevægede han sig ned over Bruuns-Bro i retning mod Rådhus Parken, men uden at give agt på byens synlige detaljer - herunder liget af Adam Aftenbakke ved springvandet, Agnete og Havmanden. Alsters distraktion var farlig for byboen, den var både en beruselse og en bedøvelse, som blokerede Alsters livsvigtige selektion af sansedata. Man kunne også sige, at han befandt sig $\mathrm{i}$ en fortællesituation som var uhensigtsmæssig, nemlig romancens, som slet ikke i sin ublandede form tilsvarer den by, som står for at blive fortalt.

Alsters mangel på opmærksomhed er lige så farlig som Sherman McCoys i Tom Wolfes The Bonfire of the Vanities (1987), da han tager "the wrong turn" ind i The Bronx. Som Sherman falder fra Wall Streets tinder, hvor Universets Herrer regerer, falder Alster fra sin momentane beruselse i romancen ind i den retssag, hvor han hurtigt finder sig dømt for mordet på Adam Aftenbakke. Han er nu næsten rede til at indtræde i en fortælleform, som tilsvarer byens trusler og byboens nøjeregnende sansning: En Monte Christo-agtig hævnhistorie og en kriminalfortælling, som skal føre ham til Aftenbakkes virkelige morder. Og en dag bryder verden ind til Alster i cellen - fra nabocellen taler medfangen Gustav Nonnetit til ham gennem vaskens afløb og opfordrer ham til flugt. Alster dukker nu op i Århus med det ene mål at hævne sig på sine bødler, dommeren Mikkel Deden, journalisten Laura Jenssøn og politikommisær Thomas Ard, altså inkarnationer af en dobbeltdømmende og den udøvende magt (ikke uvæsentlig mangler den lovgivende).

Endnu en tid er Alster bedøvet og slås af byens virvar, men hans radikale fremmedhed gør det muligt at manøvrere i byen: „uden social position, familiær baggrund, reglementeret kostumering og så videre og så videre, ville man være identitetsløs".
Alster er ikke anonym, men uden stabil identitet - fysisk og psykisk skifter han forklædning og fungerer i alle de sociale grupperinger, som Århus beskrives igennem. Byens ordentlige funktionsopdeling i kvarterer og sociale sfærer interferer, hvor Alster kommer frem og der sker en ny-ordning af forskellige planer, det sociologiske, det byplanmæssige, det narratologiske. Madsens Århus er som sagt ikke beskrevet gennem byens dimensioner, men gennem dens bevægelse og sociale praksis. Romanens samlede bevægelse er en ornamental bølgen mellem vaskens afløb $\mathrm{i}$ Horsens Tugthus og romanens slutning, hvor Ludvig Alster forsvinder med Århus ̊̊ for at mure sig inde i en niche under Åboulevarden.

\section{Indflyvining til Rådhuset}

Alsters forhold til byen er ikke overblikkets, snarere bevæger han sig ad dens om- og vildveje. Romanens store vue over byen skyldes en panoptisk fortæller; Ato Vari. Vi flyver ind ved begyndelsen til romanens andet bind:

Nærmer man sig Århus fra oven, er den først en gråbrun masse, af facon som en nyre. Fra alle sider er den afgrænset af skarpe farver, mod øst det blågrønne hav, mod nord og syd de to grønne skove og mod vest gule marker og den blå Brabrand sø. Mellem sø og hav bugter Åen sig som en blå strøm, der dog på det sidste stykke før udløbet er overdækket og derfor usynlig.

Nærmere på udskiller sig de seks-syv store veje der fører væk fra byen, og den gråbrune masse opløser sig i forskellige områder. Der er det mørke dunkle område, der dannes af de anløbne, tætsammenklinede huse i den gamle bydel. Der er det lysere og klarere forretningskvarter. Længere fra midten ser man de næsten hvide og skinnende områder, hvor prægtige beton-komplekser dominerer. Og rundt omkring ligger de lysegrønne områder, hvor villaerne mediegen have er samlede.

Gadernes fletværk, hvor bilerne strømmer. Husenes tage, skrå og flade, røde, gule og sorte. Menneskelige prikker, enlige, i store flokke, to og to sammen.

Lydene: råb, latter, advarselsskrig, reklamebrøl. Lugtene af mad, af harsk olie, af urin, blomster og bilos.

Den hvide stribe sand, der adskiller nyren fra havet. Og pludselig detaljer i en så overvældende mængde, at man fristes til at kaste sig ud i dem, ude af stand til at modstå denne uordentlige, farverige vrimmel. ${ }^{6}$ 
Fortælleren nærmer sig fra en overeksponering af by-romanens klassiske overblikssituation - fra mere end tårnhøjde eller blikket ind over byen fra en af dens høje; her kommer fortælleren ind fra fly-højde. Byen ligner da en nyre, den får sine dimensioner fra landskabet: Skovene, havet og agerlandet - og det hele gennemskæres af den famøse å, som i 900-tallet gav Århus navn, Aros eller 'Åens Munding'. Åen er en sluse, mellem land og hav. Mens Åens overdækning både er et faktuelt led i byens sene modernisering, en topos og en narrativ signifikans i Ludvig Alsters veje gennem byen, ${ }^{7}$ forbinder Åen fra flyhøjde byens city-scape og det omgivende landskab, samtidig med at det betydningsbærende forhold mellem $\AA$ og by angives ved byens nyre-form.

Tættere på træder byens kvarterer frem: Den gamle bydel, industrikvartererne og to slags boligområder, blokkene og villaerne. Altså et socio-scape, hvis udløb er transportårene - vejene „fører væk fra byen” og synes både at begrænse og dræne den. Billedet af Århus fra denne højde er uendelig generelt - mere generelt end den overliggende indflyvningshøjde, hvor dog landskabets signifikans (parret med navngivningen: Brabrand sø og Ån) gør byen genkendelig i sin partikularitet. Som socio-scape er Århus anonym; den ligner enhver middelstor, dansk provinsby, som igen i sin funktionsdeling ligner den modernistisk radiale regulering af byens udvidelse. Det èr denne abstrakte by, som er udgangspunkt for fortællingen om Århus.

Først tæt på, ved "gadernes fletværk", får Århus et storbypræg: Det pointilistiske menneskemylder, angrebet på nærsanserne, lydenes og lugtenes kaos. Først hér får vi bekræftet', at der er tale om en indflyvning, altså mere end en abstrakt bevægelse, idet vi får en skrå vinkel på sandbræmmen mellem hav og land. Fortælleren kommer fra havsiden, gennem Åens gamle sluse, og opsluges så af byen: „Denne uordentlige, farverige vrimmel”. Indflyvningen mimer det perspektiviske dilemma mellem overblik og detailrigdom, som man finder i det 19. århundredes byskildringer. Den der foretager indflyvningen er romanens fortæller fra out of space eller fremtiden: Ato Vari, som nu lander øverst på Rådhustårnet for at „ophøre at være Ato Vari. Jeg må være dér for at opleve det. Jeg må påtage mig en krop som deres. På min egen krop må jeg prøve mangfoldigheden. Dette er livet. Jeg må prøve det."

Tugt og utugt i mellemtiden har hele tiden været Ato Varis konstruktion, en bog om Århus: „Jeg er Ato Vari. Nu vil jeg skrive en bog. Bøger læste man før i tiden". Ato Vari er en mager eller en demiurg - en dæmonisk eller panoptisk fortæller. Men Vari fristes af byens liv eller rettere af en bestemt fortælleform: „Jeg lader mig rive med. Ville beskrive menneskene, men føres på vildspor af de særprægede, farverige ceremonier, de bizarre, de barbariske men fascinerende omgangsmåder". Vari inkarnerer sig derfor i sit eget skaberværk, i drengen Sjat, der inde fra fortællingen er blevet skabt som fortælle-bærer af forfatteren Steen Pekoral, som ikke kan skrive om mennesker, men kun skabe verdener. Denne treenighed inkarnerer parodisk romanens perspektiviske dilemma.

Pointen er sådan set ikke, at Madsen benytter perspektivteknikker fra det 19. århundredes by-roman i gestaltningen af sin treenige fortæller og i sin metropolisering af Århus. Pointen er, at perspektivforvirringen distribuerer byens genkendelighed på en ganske bestemt måde, som hverken er overbliks- eller detailoptikkens; men som det siges af Ato Vari, „omvejens".

\section{Ankomst, Århus H}

Århus fortælles altså ad omveje, hvilket ikke er umiddelbart givet ved det første blik på byen, efter at Ludvig Alster er ankommet til byen. Den følgende passus findes under overskriften „Byens orden":

Ved første blik et kaotisk mylder, men et grundigere eftersyn afslører at byens folkemængde er inddelt $i$ talrige skarpt afgrænsede grupper, der nøje følger et tusindtal af regler, der sikrer at mønstret ikke brydes.

Visse inddelinger markeres tydeligt og åbent, andre betragtes som tabuemner og omtales aldrig, skønt alle har kendskab til dem, nogle kommer frem ved samtaler, andre ved optræden.

[...]

Men systemet er så omfattende at det ikke lader sig fremstille i detaljer. Der findes mennesker der har forpligtet sig til at bære læderjakker, - nogle skal have håret af en ganske bestemt længde, nogle skal bære lak- 
tasker, nogle har lovet at fjerne hårværksten fra deres kinder hver eneste dag. Nogle ville føle sig upåklædt uden hat, andre vil ikke for nogen pris bære hat indendørs. Det tøj man bærer om natten har man ikke lov a vise sig $\mathrm{i}$ om dagen, er en uskreven regel for adskillige af grupperne. Sætter man blåt og grønt sammen placerer man sig i én gruppe, har man knappet jakken, men undladt at knappe bukserne tilhører man en anden. 8

Her beskrives en tilsyneladende sociologisk kompleksitet, som ikke desto mindre er lige så funktionel som byplanen. Der er visse regler, som ganske vist ifølge romanens fortæller ikke lader sig beskrive in toto, men som praktiseres uafladeligt og nøjagtigt. Dette er byen, som Alster møder ved sin tilbagekomst, ${ }^{9}$ Byens sociale landskab udgøres af en overflod af moduler og koder, som nok er fremstillet let forvrænget (gennem fortællerens blik fra fremtiden), men som går restløst op i en højere enhed. Byen er, for igen at bruge romantitlens ord, tugtet. At fortælle byen vil således ikke sige at bibringe den hverken helhed eller orientering, men tværtimod at fratage den fasthed.

-Der er et forløb mellem orden, fortælling og kaos i Tugt og utugt $i$ mellemtiden, som kan beskrives i affinitet til bestemmelser af den moderne by som henholdsvis place og space - og i affinitet til disintegrationen af et modernistisk by-ideal, der fremstår rendyrket ved midten af det tyvende århundrede: En by, der er defineret ved sine funktionsområder, en offentlig og professionel sfære, en privat sfære og en rekreativ sfære; hvor altså City er centrum for radialer af beboelse, industri og grønne områder. Madsens renarrativisering af byen lader sig læse som en fortællestrategisk pendant til en række by-arkitektoniske opgør med modernismens funktionelle by. ${ }^{10}$

Hvis vi tager udgangspunkt $i$ „Byens orden” samt i forfatteren Steen Pekorals forsæt - at lade drengen Sjat opfylde, hvad han ikke selv formår, 'at fortælle menneskene' - er byens socioscape romanens vigtigste narrative felt. Byen er et rum af sociale praksis'er, før den får material volumen; med by-sociologiens begreber er den derfor space før den bliver place. ${ }^{11}$ Men hvor man i nyere by-analyse forstår dette 'space' som et virtuelt og i sin hel- hed uoverskueligt rum af kommunikation og transport, er funktionsopdelingerne mellem de enkelte rum i Byens orden, trods forsikringer om det modsatte, ikke tilstrækkelig komplicerede til at etablere en fortælling. De enkelte grupper tilhører for dem selv genkendelige rum, hvorfra de manøvrerer i byens genkendelighed. Byens udadtil faste grænser synes at reproduceres indadtil i dens sociale landskab. Imidlertid kunne man sige, at byen som socio-scape allerede virtuelt rummer en perspektivisk mangedobling af sit ene, begrænsede rum gennem alle sine mange miljøer, som hver især udgør en mulig variant af det århusianske. „Byens orden”, som Ludvig Alster møder den, er potentielt polycentrisk.

Det er denne polycentriske perspektivisme, som er Madsens by-plan. Fordi Århus altså ikke er en metropol, fordi byen hverken de facto eller i forestillingen om dèn har en endeløs udstrækning eller en stor intern kompleksitet, men har ganske faste grænser inden for og omkring sin nyreform, må den rumme mulighed for at fare vild på en anden måde, og denne vildfarelse er det Ludvig Alsters opgave at etablere.

Romanen består af et antal hovedfortællinger, der forbinder sig til Alsters bevægelser gennem byen som en række indbyrdes uforbundne perspektiver på mordgåden: Tyrkerpigen Lilaiomai, som kun har en ring til at minde sig om den aften i 1962, hvor noget uhyggeligt skete; arkitekten Esper Rimby, der samme aften mistede sin ring; Bernhard Aftenbakke, hvis far blev myrdet, hvis kone er Alsters ungdomskærlighed og hvis søn forelsker sig i Lilaiomai. Dommer Deden, som er altfor retfærdig og forveksler ret med godhed; kriminalkommisær Ard, som inkarnerer ondskaben og altid har retten til det på sin side - og fx. bruger denne ret til at holde Lilaiomai fanget som sit tyende. Bedsteborgeren Emil Bønhase, som er kommet i klammeri med Lilaiomai; men som senere bytter identitet med Skæven, Alsters medfange og flugtkammerat, også kaldet Nonnetit. Emilie Bønhase, som udnævner Alster til sin ridder og starter en ø-lejr på en holm i Brabrand sø.

Hele byen involveres gennem sine sociologiske typer i en omfattende vækst af vildveje, omkring Alsters hævnplan gestaltes 
et netværk af personer, miljøer, objekter - imellem hvilke fortællingen bliver til. At fortælle Århus afhænger i Tugt og utugt i mellemtiden både af Alsters mulighed for at være $\mathrm{i}$ byen og alligevel ikke at være der og af, at byen har en social genkendelighed, at den altså er typificérbar.

\section{Topografi og typologi}

For at få greb om, hvordan Århus fungerer i Svend Åge Madsens romaner, må man forstå, hvordan genkendeligheden fungerer i fremstillingen af byen. Svend Åge Madsen betjener sig - som det fremhæves af Jan Kjærstad - ikke af en egentlig miljø-beskrivelse, men snarere af et kartografisk fremstillingsprincip, nemlig topografien.

Topografien er en genre i både litteratur og billedkunst. Litterært er der tale om en stedsbeskrivelse med fremhævede detaljer, men uden panoramaets fantasmagoriske effekter. Forskellen bliver tydeligere, hvis man betragter genren inden for billedkunsten, 12 hvor topografien er en fremstilling af et landskab eller en by, som tilstræber orientering snarere end symbolsk sammenhæng. Det topografiske billede finder sin form i det 17. århundredes landskabsstik, som ved første blik forekommer 'realistisk'. Men dette indtryk af virkelighedsnærhẹ opstår gennem optisk forkortning, altså ved et perspektivisk bedrag, som afstedkommes gennem overdimensionering og tydeliggørelse af markạte punkter i det afbildede. De markante punkter er pejlemærker for genkendelse og bevirker yderligere, at perspektivliniernẻ spredes i modsætning til landskabsmaleriets centralperspektiv. Topografien ligner et landskabsmaleri, men ér et kort.

Topografien er altså en stedsbeskrivelse, som gennem forvrængning af enkelte punkter fremstiller en genkendelig helhed for blikket. Der er tale om en selektion, men især om en overeksponering af det selekterede - alt dette for at etablere orienteringslinier mellem pejlepunkterne.

Ved romanens udgivelse vakte detailrigdommen i Tugt og utugt $i$ mellemtiden opsigt. Kun i den forudgående roman, Jakkels van- dring, fra 1974, havde Madsen arbejdet med et identificerbart univers, og i sammenligning med Jakkels vandring er universet $\mathrm{i}$ Tugt og utugt $i$ mellemtiden uhyre komplekst. Kompleksiteten er imidlertid mindre et resultat af, at byen beskrives meget detaljeret, end af, at Madsen etablerer mange perspektiviske eller narrative linier mellem sine få, men til gengæld markante og genkendelige pejlemærker, som hentes fra både fortælleteknikkens inventarium og fra byens faktuelle og sociologiske kort. Her kan man sammenligne med Jan Kjærstads distinktion mellem feltromanens eksperimenterende samordninger og dens traditionelle eller genkendelige enkeltfortællinger. Når det gælder både Kjærstads Oslo-romaner og Madsens Århus-romaner, er det væsentligt at fastholde en forskel mellem kartografisk nøjagtighed og en egentlig beskrivelse - det århusianske byrum i Tugt og utugt i mellemtiden er in extenso blot tilsyneladende tilforladeligt, omend dets genkendelighed i det enkelte er uafviselig.

Handlingen i Tugt og utugt $i$ mellemtiden udfolder sig hovedsageligt $\mathbf{i}$ den indre by, $\mathrm{i}$ et område mellem banen og åen. Igen ser vi denne interesse for 'årer' og 'sluser', det er ikke tilfældigt, at Ludvig Alster kommer ind med banen fra syd og ved romanens slutning forsvinder ind under Åboulevarden. Ud over den centrale by er der radialer til kvarteret omkring Asylvej i den pæne forstad Risskov, som imidlertid også rummer Statshospitalet og Psykologisk Institut; til det gamle borger- og parvenukvarter fra århundredskiftet, som ligger i bykernens sydlige udkant, omkring Marselisborg Slot; og endelig til en uplacerbar beboelsesejendom, Skærvej 7, i en mere lurvet del af forstæderne. Skærvej findes ikke i gadefortegnelsen over Århus; den er en skæring eller grænse i Madsens fiktion. Her mødes romanens hovedpersoner i forskellige konstellationer, men i reglen uden for det offentlige rum. Her bor Ludvig Alster med sin flugtkammerat, Gustav Nonnetit eller Skæven, og her bor forfatteren Steen Pekoral med drengen Sjat (og Ato Vari). Her mødes altså byrummets usynlige koordinater og romanens fiktionssløjfer.

Går vi tættere på Madsens topografiske by-kerne finder vi bl.a. følgende pejlepunkter: Gaderne Graven og Guldsmedgade i det gamle 'minefelt' og stederne Rådhuset, springvandet Ag- 
nete og Havmanden, Grand Hotel, Banegården og den famøse Århus Å. Pejlepunkterne er markante eller typiske som i topografien. Det er stort set orienteringspunkter, som man ville finde i en turistbrochure, altså seværdigheder. Pejlepunkterne er imidlertid ikke optegnet ud fra deres offentlige eller seværdige funktion. Således hører man hverken om, hvad der foregår inde på rådhuset eller hvornår og af hvem det ellers berømte, funktionalistiske Rådhus er bygget. Pejlepunkterne er tydeligvis narrative knudepunkter: Liget af Adam Aftenbakke findes ved Agnete og Havmanden og en sen nattetime finder en duel på puder sted på toppen af rådhustårnet. I Guldsmedgade finder vi en bomberuin, hvor heltinden Lilaiomai holdes indespærret af læderjakkerne, og kvarteret omkring Graven er et grotesk-forstørret billede af det minefelt, der engang var; men hvor også de tilsyneladende gode borgere, kriminalkommisær Ard og Bernhard Aftenbakke, har til huse mellem ludere og lommetyve.

Madsens pejlepunkter er både offentligt tilgængelige og ikke for offentlige i deres betydning. Det er fx. en overvejelse værd, at hverken retsbygning, politigård eller bladhus, hvor ellers Alsters bødler og ofre har deres offentlige domæne, placeres topografisk; mens rådhuset, som kun fremstilles som en ydre arkitektur, bliver narrativt fremhævet og genkendt. Fra opmærksomheden på de topografiske pejlemærker kunne man spørge til den baggrund, de tegnes op mod. Hvad med resten af byen? Holder vi os stadig til den indre by, kunne man igen i sammenligning med det 19. århundredes byromaner hæfte sig ved, at teatret eller operaen og varehuset ikke fremhæves som pejlemærker. Operaen og varehuset er sammen med gaderummet par excellence metropolens dobbelte scene, hvor massen opfører et skuespil af ornamenteret bevægelse, som den enkelte både beskuer og agerer i. Masseteatret finder man imidlertid også hos Madsen, men henlagt til gader og især pladser, hvor en forestilling ceremonielt iscenesættes $\mathrm{fx}$. i forbindelse med rettens skueprocesser. Disse forestillinger mimer også fiktionens egen referentielle detaljering, således også ved den anden rekonstruktion af mordet på Adam Aftenbakke:
Politiets rekonstruktioner var altid populære, dramatiske skuespil med en virkelig baggrund, som de var, overgik de hvad biografer, teatre og fjernsynet kunne byde på. Måske kendte man endda ofret eller forbryderen, eller man fik lejlighed til selv at medvirke. Det var hændt at et tilfældigt vidnes iagttagelser under rekonstruktionen, havde haft en afgørende indflydelse på dommen.

Men når rekonstruktionen angik en sag, der var mere end ti år gammel, steg interessen til enorme højder. Dette var en lejlighed til at genopleve de gamle dage. Og i 1975 føltes 1962 virkelig som en svunden epoke. Kom en bil, hvoraf fabrikationen først startede i 1965, ind i det pågældende område, blev den straks piftet ud af en forarget skare. En kjole der var kortere end moden i 1962 tillod, vakte om muligt endnu større forargelse, end den ville have gjort i det rigtige år 1962. Ud gennem vinduerne lød der skrattende plader med den tids populære melodier. Biograferne skiftede repertoire, en del forretninger ændrede priser for en enkelt dag. ${ }^{13}$

Det retslige ceremóniel kan betragtes som udpegningen af en bevægelse i den urbane menneskemasse, der ligger uden for byens faste orden, typificerede personer og topografiske pejlemærker. En metropol-agtigt bevægelse, kunne man sige, men også en bevægelse, som (hvis man $\mathrm{fx}$. henholder sig til Siegfrieds Krakauers bestemmelse af massens ornamentik i „Das Ornament der Masse" (1927)) vanskeligt lader sig narrativisere.

Forfatteren Steen Pekoral kan ikke fortælle mennesker. Det problem er på sin vis gennemgribende for Tugt og utugt $i$ mellemtiden og forbinder, trods romanens begrænsede og provinsielle univers, Århus i Madsens roman med komplekset 'metropol og modernitet'. Metropol-mennesker lader sig vanskeligt beskrive gennem andet end ekstreme typificeringer, altså som givne funktioner af en kulturtilstand. Det samme kạn til en vis grad siges at være tilfældet med Madsens personer.

Typen forbinder hos Madsen byens orden og dens amorfe massebevægelse. Den socialt transparente orden, som vi præsenteres for ved romanens begyndelse, er et udslag af massens funktionsduelighed, det er en orden af reguleret bevægelse og et symptom på massemenneskets identitetslabilitet. Dette viser sig i gestaltningen af persongalleriet omkring Ludvig Alster. Alster selv er aldrig sig selv, han er snart jurist, snart arbejder, betjent el- 
ler bokser: „Han påstod selv, at han ikke kunne falde ud af en rolle, for der var ikke noget andet han kunne falde over i. Det gør jo sagen lettere." Samtidig med at Alsters labile identitet åbner et sociologisk rum for fortællinger, sker der spaltninger i det sociologisk definerede persongalleri. Ikke alene etableres der forbindelser på tværs af sociale grupperinger, men også på tværs af individet som entitet. De ekstreme typificeringer taler i sig selv for, at typerne er udhævede masseindivider, som er rent funktionsbestemte og derfor kan redirigeres i en anden koreografi, hvilket sker: Bernhard og Irmelin Aftenbakkes forelskede søn, Christian, fordobler sig, så han kan opfylde sit dobbelte begær, at flytte sammen med Lilaiomai og gifte sig socialt acceptabelt med den pæne Mille Bønhase. Forbryderne Gustav Bønhase og Herman Bimpel går mentalt i en slags Jekyl-Hyde-fordobling med bedsteborgerne Emil Bønhase og Einvald Deyk.

Antallet af dobbeltgængere, identitetsskiftere, halve mennesker og mentale eller korporlige osmoser tager til mod romanens slutning. Byens tårne, dens undergrund, dens stræder og trappeopgange mister deres - trods den topografiske overdimensionering - svage identitet $i$ bybilledet og bliver varierende scener for uventede og groteske møder mellem personer, man ikke kan være sikker på, hvem er. Der lægges op til en grad af 'uorden' i byen, som - $\mathrm{i}$ lighed med romanen At fortælle menneskene - kunne effektuere en apokalypse, en overopfyldning af narrativ kompleksitet. Men det, der umiddelbart kunne ligne en grande finale, hvor Ato Vari efter sin inkarnation som en regulær deus ex machina løser alle konflikter og hvor alle får hinanden eller finder deres mistede halvdel, er også typernes og de topografiske pejlemærkers fald tilbage i en orden. Hvad romanen i sit mellemrum har præsenteret, er en labil (og meget metropolagtig) identitet under det funktionelle socio-scape, som romanen åbnede med, og hvad vi har været vidner til, er denne masseidentitets prædisposition for fortælling.

\section{Place og space}

Fordi byens genkendelighed har denne efemere og dog abstrakt nøjagtige karakter, kan man sidestille renarrativiseringen af massen i Tugt og utugt $i$ mellemtiden med by-sociologiske diskussioner af det modernistiske byrums overgang fra place til space (se note 11). Der er groft sagt tale om en overgang fra metropolen, som vi kender den fra det 19. og tidlige 20. århundrede som et sted, til det modernistiske storby-rum, hvis ideal er en gnidningsløs kommunikations- og transportmaskine omkring det funktionelle massemenneske, the orgman eller "the organization man". Forskellen mellem det 19. århundredes metropol og den modernistisk funktionelle storby formuleres således af den hollandske arkitekt, Aldo van Eyck:

I stedet for ubehaglig snavs og forvirring har vi nu fået hygiejnens kedsomhed. Den materielle slum er forsvundet - det er den for eksempel i Holland - men hvad har erstattet den? Kilometervis af reguleret intetsteds [organized nowhere], hvor ingen kan føle, at han er'nogen som lever nogetsteds'..$^{14}$

Citatet er hentet hos litteraten og arkitekturteoretikeren, Charles Jenks, hvis Modern Movements in Architecture (1973/1985) sammen med fx. Robert Venturis og Aldo Rossis teoretiske skrifter og arkitektoniske praksis var med til at indføre et begreb om renarrativiseret arkitektur og introducerede forudsætningerne for en postmodernistisk arkitektur ved 1980 'ernes midte. I bogen beskriver Jenks forestillingen om the 'org-man' således:

Ved slutningen af halvtredserne havde sociologer tegnet konturerne af Orgman. Han var, som man kunne formode, fundamentalt ikke beskrivelig, men for så vidt som man kunne tilskrive ham en karakter, var den snarere 'other directed' end 'inner directed'; det vil sige snarere formet af socialt bestemte kræfter end af individuelt formulerede målsætninger. [...]

byboerens liv var ved at blive mere anonymt og mobilt, eller i arkitektur-termer var der en bevægelse fra symbolsk rige systemer til fattige, fra kulturelt til funktionelt bestemte roller, eller ganske enkelt fra 'place' til 'space'. ${ }^{15}$ 
Indvendingen mod den modernistiske bys karakter af space var, at den i sin ideale funktionalitet mistede al narrativitet, og at byens tab af narrativitet var forbundet med et tab af partikulær genkendelighed og ydre form, altså kort sagt med tabet af dens karakter af place. Man kunne sige, at den modernistiske funktionalitet nok var et idealiseret space, men at dens ophævelse af byens materielle partikularitet var en strengere og mere gennemgribende regulering end storbyernes modernisering gennem det 19. århundrede, netop fordi den modernistiske byplan får global generalitet. Det er denne generalitet, som vi genkender i Tugt og utugt $i$ mellemtiden ved fortællerens indflyvning over Århus, på det sted hvor byens opdeling i kvarterer træder frem. Ikke for ingenting udspringer den modernistisk regulerede byplan af den såkaldt 'internationale stil', som Gropius, le Corbusier og Mies van der Rohe stod faddere til.

Indvendinger mod den modernistiske funktionalisme kom bl.a. fra en række såkaldt neo-rationalistiske arkitekter, som begynder deres virke i 1970'erne med at applikere steder i byens rum. Det vil sige, at disse arkitekter arbejder med at differentiere byen gennem partikulært genkendelige typificeringer̀. Arkitekterne - bl.a: italieneren Aldo Rossi og hollænderen Leon Krier arbejder ind i det eksisterende byrum ved at anlægge eller fremhæve fx. pladser eller monumentale bygninger i en ellers anonym sfære. De arbejder således ikke på at centralisere byen, men nærmest på at gøre den til en topografi, dvs. at gøre byen partikulært genkendelig for en symbolsk, bymæssig praksis, som celebrerer massemenneskets bevægelighed på samme måde, som Svend Åge Madsen med politiets rekonstruktioner gestalter byen som totalteater.

En meget kortfattet bestemmelse af neo-rationalismen kunne lyde: centrumsløs klarhed, hvilket med ord fra analysen af Tugt og utugt $i$ mellemtiden kan omskrives med 'polycentreret typificering'. Forestillingen om igen at sted-fæste byens offentlige sfære knytter sig nemlig til arkitektoniske typer og moduler, idet der arbejdes i en vekslen mellem serialitet og pludselig iøjnefaldende variation: Et spring i højde, et enkelt vindue uden sprosse, som fremhæver typen i et ellers serielt forløb. Typen og modulet finder man såvel i bygningskonstruktionen - vinduer, tage, etager - som i byplanens pladser, monumentalbygninger og anlæg. Lad mig citere Leon Krier fra "Rekonstruktion af byen” (en katalogtekst til udstillingen Rationel arkitektur $i$ London, 1975), hvor han under overskriften Det offentlige domæne opridser neo-rationalismens temaer:

- Den fysiske og sociale bevarelse af de historiske centre som ønskværdige forbilleder for kollektivt liv.

- Opfattelsen af byrummet som det primære organiserende element $\mathrm{i}$ storbyens morfologi.

- De typologiske og morfologiske studier er grundlaget for en ny arkitektonisk disciplin.

- Den voksende bevidsthed om, at byens historie leverer præcise kendsgerninger, som gør det muligt at gå i øjeblikkelig aktion med rekonstruktionen af gaden, pladsen og kvarteret.

- Forvandlingen af beboelsesområder (sovebyer) til komplekse bydele, til byer i byen, til kvarterer som integrerer alle bylivets funktioner.

- Genopdagelsen af de grundlæggende elementer i arkitekturen: søjlen, muren, taget osv. ${ }^{16}$

Neo-rationalismens pointering af betydningsdannende udveksling mellem arkitektonisk typificering og narrativitet har meget tilfælles med Madsens arbejde med både typificering af massen på tværs af det århusianske socio-scape og hans arbejde med topografiske pejlemærker. I begge tilfælde er der tale om forsøg med en renarrativisering af et modernistisk nulpunkt eller intetsted: Byerne hos Krier, Rossi og Madsen er forsøgsstationer for en verdensskabelse. Forsøgene går over en re-teatralisering, et forsøg på at skabe orienteringsmærker eller gelejde massen ind på scener i byens rum. Og både arkitektens og romanforfatterens forsøg finder sted i et grænseland mellem kosmogoni og apokalypse:

Til den ene side arbejdes der med nedbrydningen af typen i moduler. Madsen nedbryder sine typer i sociologiske ledemotiver og i.ord-mennesker (dette er tydeligere i At fortælle menneskene, men sætter sig også igennem i fx. navneregisteret i Tugt og utugt $i$ mellemtiden, jvf. Adam - Bernhard - Christian Aftenbakke), mens neo-rationalisterne bl.a. vender sig til den klassicis- 
tiske arkitekt J-N-L Durands morfologi. Forskellen mellem neorationalisterne og funktionalisterne er her ikke indlysende, med mindre man holder sig for øje, at morfologiens enkeltelement forstås som betydningsbærende, en betydning, som udfoldes narrativt i samordningen med andre elementer.

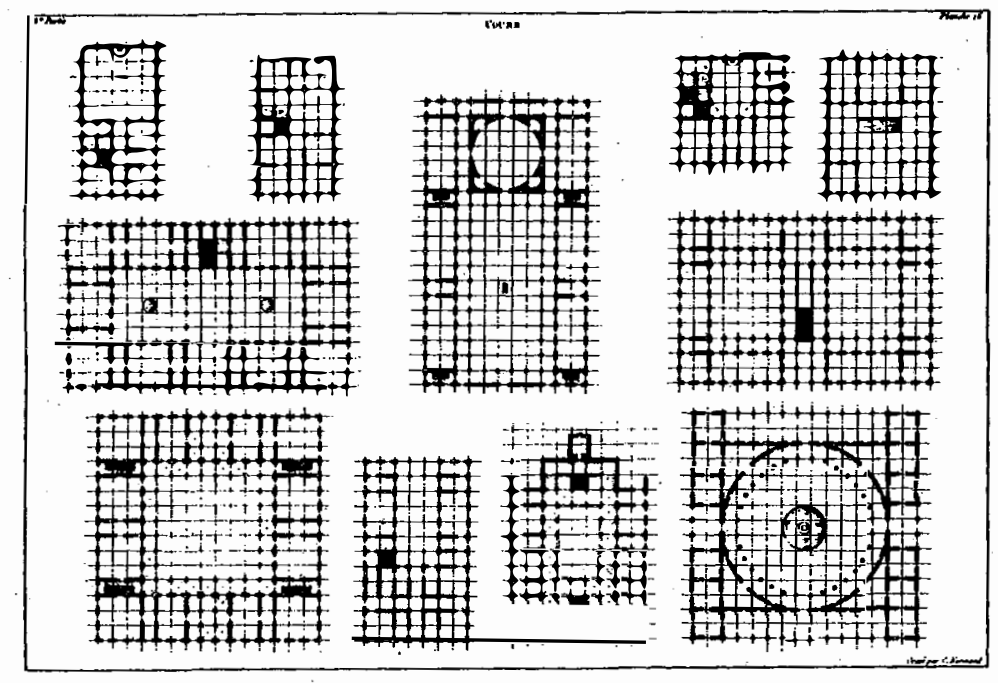

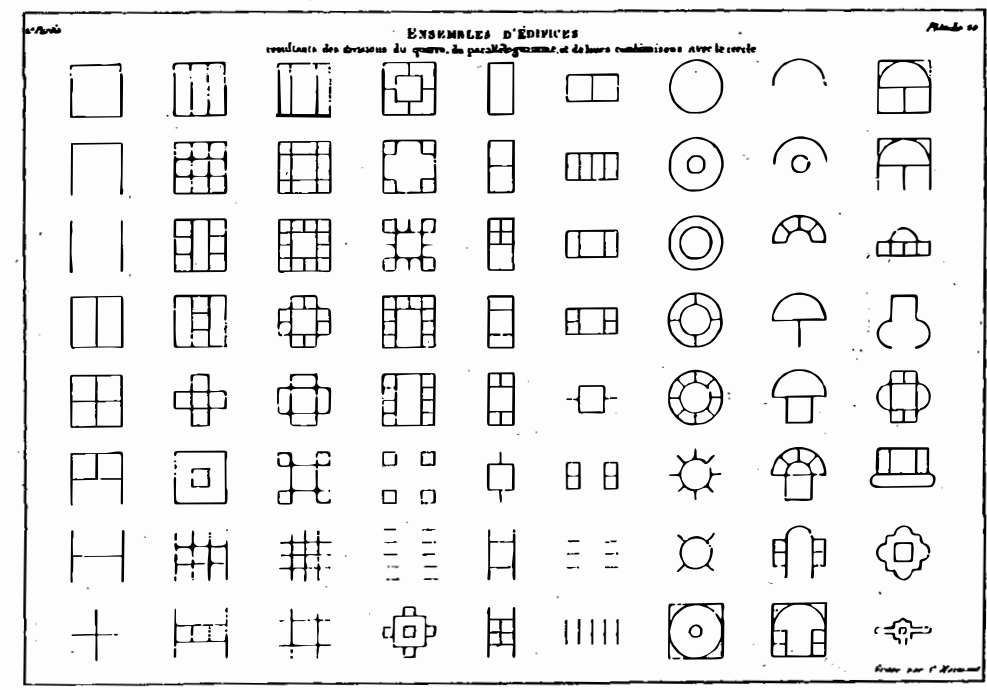

J-N-L Durand (1760-1834): „Typer“
Til den anden side arbejder både romanforfatteren og arkitekten henimod en tilvækst af narrativitet inden for byens allerede givne rum, som i sin prioritering af omveje og 'vildfarelser'- af det collageagtige rum, som vi ser i Aldo Rossis fiktion over en byplan - næsten nærmer sig det kaotiske, eller i romanens tilfælde, overopfyldningen af narrative elementer og formens muntre apokalypse.

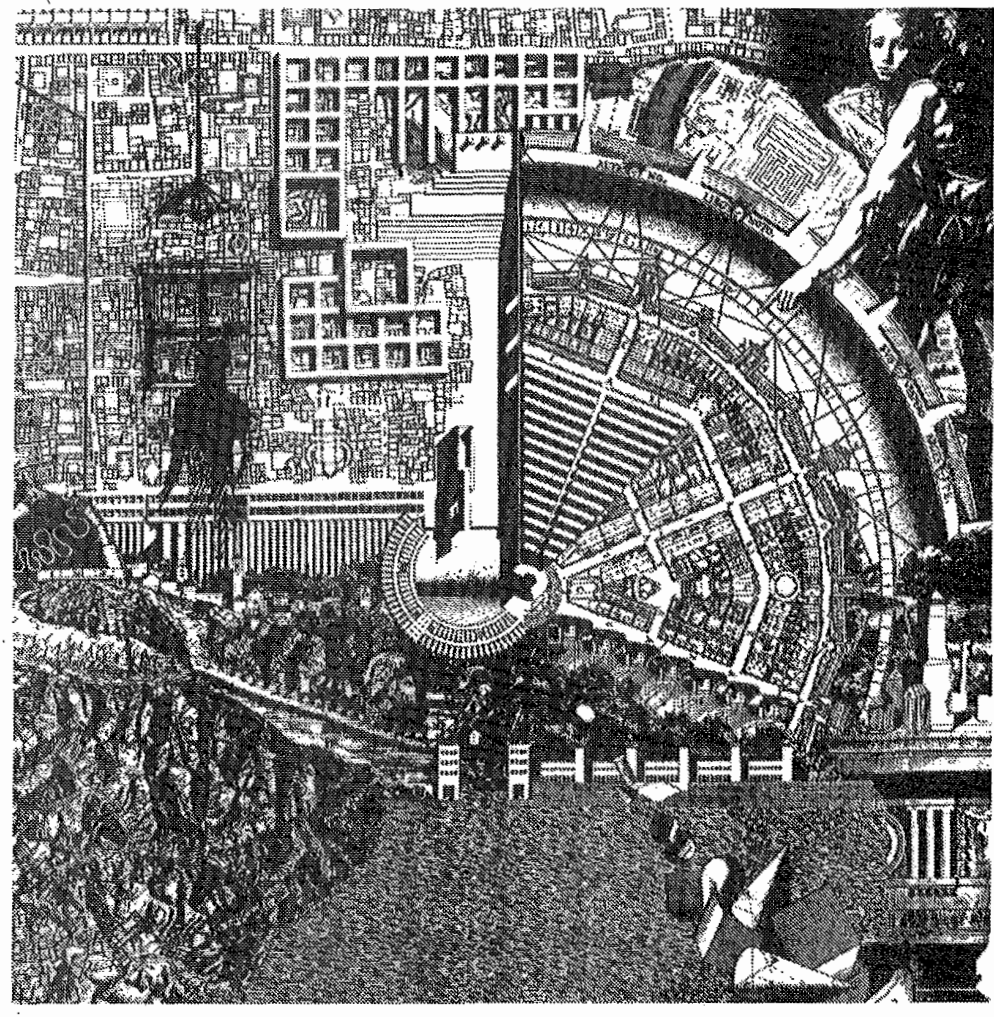

Aldo Rossi: „La cittá analoga“, 1976

Rossi eksperimenterer $\mathrm{i}$ „La cittá analoga“" med en collage af typer under henvisning til en 'additiv syntaks', som kun lader rumlig betydning danne sig ad hoc gennem de enkelte elemen- 
ters forhold til det omgivende og ikke i forhold til en overordnet plan.

Som en sidste understregning af det topografiske princip for partikulær genkendelighed kan man tage OMA's berømte The City of the Captive Globe, som - måske i lighed med Madsens kosmogoniske bestræbelse for sit århusianske univers - kan læses som en inversion af Marshall McLuhans totale space, The Global Village. IOMA's projekt omdannes metropolen gennemgribende til et netværk af topografiske punkter.

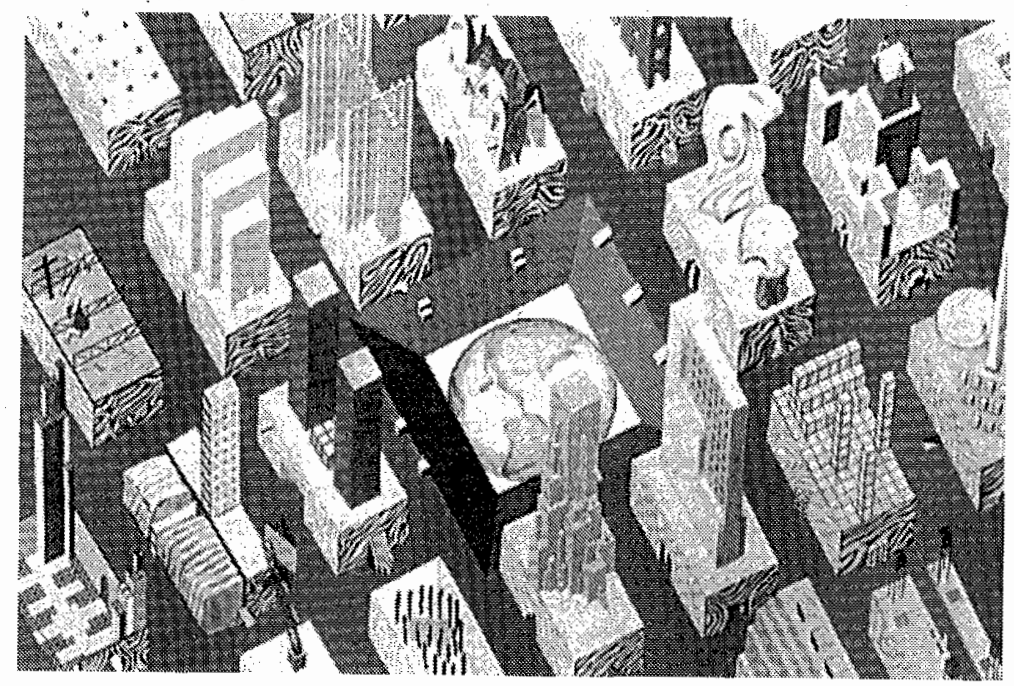

OMA (The Office of Metropolitan Architecture): „The City of the Captive Globe", 1972

Man ser Manhatten skåret op i isolerede blokke, omkring The Captive Globe, som i billedets centrum svæver under byens anonyme grundflade. Den enkelte blok er et arkitektonisk eller quasi-arkitektonisk citat, og samordningens heterogenitet synes at give udtryk for, at isolationen i metropolen fremmer begæret efter orientering, her ikke en funktions-, men en billedbestemt orientering i lighed med Madsens se-værdige, topografisk og sociologisk genkendelige Århus anno 1975.

Balanceakten i Tugt og utugt $i$ mellemtiden mellem byens space og place er lige så dilemmatisk som spillet med romanens temporale og fortællermæssige paradokser. Pointen hos Svend Åge Madsen (som hos neo-rationalisterne i deres arbejde med forholdet mellem serialitet og brud) er en insisteren på simultaneitet mellem fiktionens kompositionelle 'tricks' og by-fremstillingens genkendelige detaljer og sociale praksis. Den topografiske genkendelighed, detaljernes evidens, den irriterende og iøjnefaldende historicitet $\mathrm{i}$ romanens sociale utopi, som det måske kunne være behageligt at skrabe af konstruktionen, er ikke desto mindre et ornament, som bidrager væsentligt til den rumlige utugt og energi i Madsens Århus-roman.

I min omtale af fortællertriaden nævnte jeg, at Madsen nærmest parodisk udpeger det perspektiviske dilemma mellem overblik og detailrigdom, som hjemsøger, men også potenserer fortælleroptikken i det 19. århundredes by-romaner. Madsen udpeger dilemmaet, men løser det i sagens natur ikke. Som en afsluttende sløjfe på, hvorfor Århus hos Madsen ikke er en metropol som Paris $\mathrm{i}$ det 19. århundrede eller Wien omkring århundredskiftet, men ikke desto mindre står i gæld til by-romanernes klassiske gestaltning af forholdet mellem metropol og modernitet, kan man sige, at hvor det gælder narrativiseringen af den funktionelt modernistiske by, hvor overblikket ikke længere etableres fra et tårn eller en høj, men gennem kortlægning af kommunikations- og transportlinièr, må der også emaneres fantasmagoriske punkter i byen som drivkræfter for romanens energi. Det gælder såvel Ludvig Alster veje mellem Madsens topografiske seværdigheder som neo-rationalisternes drømmeagtige collager og monumenter. 


\section{Noter}

1. Madsen 1989, p. 227

2. I artiklen „Tugt og utugt i mellemtiden” (Kritik 93, 1990) har jeg behandlet det groteskgjorte by-rum som en effekt af narrations- eller fiktionsspillet i romanen. I nærværende artikel er hensigten at betragte byfremstillingen i større uafhængighed af de overordnede narrative principper og paradokser hos Madsen, dog uden at en fuldstændig udskillelse lader sig. gøre. Bevægelsen fra indordningen af by-beskrivelsen under narrationsspillet til en mindre subsumerende læsning af forholdet mellem fiktions- og byrum forsøger jeg at tydeliggøre ved Jan Kjærstads to begreber eller mønstre for romanens rum, „matrisen” og „feltet"

3. "Dansk 70-tall som missing link”, in: Kjærstad 1989, pp. 129

4. I essayet „Romanen som menneskets matrise” beskriver Kjærstad sit matriserum eller sin matrisemodel på en måde, som tydeligt slår igennem $i$ hans beskrivelse af Tugt og utugt $i$ mellemtiden fra „Dansk 70-tal som missing link", sådan som denne er citeret i min brødtekst. Kjærstad beskriver sine egne romaner som opbygget af matriser, ca. en for hvert kapitel, hver matrise fremstiller mennesket, som det for Kjærstad er romangenrens anliggende at skildre - ikke direkte, men gennem fremstilling af dets omgivelser. Alle disse matriser er bygget op af detail-informationer, som har vertikale forbindelser til matriserne over og under og hvis hensigt det er at antyde, at den samme historie bliver fortalt $i$ hvert kapitel. Mennesket ligger således i en negativ form (matrisen som støbeform), udgiort af detaljer og informationer. Denne form kalder Kjærstad ornamental og som Kjærstad selv hæfter det ornamentale til hverdagslighed og evidens, er det i detaljernes evidenser og ornamenter, man skal søge det særligt dynamiske i Svend Åge Madsens by-beskrivelse: „Ornamentet kan sikkert tolkes på mange måder. For mig er det først og fremmest en måde at indlægge flere dimensioner på, en miniaturestruktur som kan korrigere, latterliggøre, af-totalisere stor-kompositionen. Jeg tænker på Vermeer. Mange af hans malerier bliver anset for at være hverdagsrealisme. Sådan har jeg aldrig opfattet dem og opdagede en dag hvorfor. Pludselig så jeg at alle hans malerier er fulde af orientalske tæpper, som ofte danner barrierer i baggrunden, et raster som øjnene må igennem; pludselig så jeg også alle de mønstrede draperier og glasmosaikker, de detaljerede billeder på væggene og kortene i baggrunden - ornamentale genstande som lader en transcendental dimension glide ind i hverdagsskildringen. For mig er ornamentet i alle tilfælde mere end pynt; det gemmer et dybtgribende etisk potentiale, gennem sine skjulte sammenhænge, krydsforbindelser og symmetrier; en slags trodsig guerillavirksomhed mod både kaos og overordnet totalitet."

(Kjærstad 1989, p. 221. Min oversættelse)
Hvis man følger den tanke, at en del af Svend Åge Madsens byfremstilling også er diskursivt bestemt, jvf. romanens sociale typologisering, får da netop det utilsigtede spind eller ornament, som har hverdagsrealistisk signifikans, men som med tiden bliver tydelige som diskursiv reference - ikke mindst, hvor det som hos Madsen drejer sig om typologisering, om en form, et skema eller en fordom.

5. Kjærstad 1989, p. 133. Min oversættelse.

6. Madsen 1976, bd. 2, p. 9 .

7. Åen udgør for Ludvig Alster en undergrund i lighed med de parisiske kloakker hos fx. Victor Hugo og i Walter Benjamins senere analyser (jvf. Passagenwerk, Afsnit C: „Antikisches Paris, Katakomben, Demolitions, Untergang von Paris"). Undergrunden er både byens forlængelse og dens anden, infernalske side - sådan skal også det glemte folk, som Alster møder under Åboulevarden, læses.

8. Madsen 1976, bd. 1, p. 66

9. Beskivelsen af Alsters første møde med byen mimer og parodierer både metropolens sanse- og perspektivforvirring og pinagtigheden og paralysen ved at være udsat for et masseblik:

"Han ved ikke hvor han skal gå. Bilerne forekommer ham små, men de viser sig at være både hurtige og farlige. Han har betvunget sin frygt for menneskene på gaden, men kan ikke vænne sig til at de alle stirrer på ham, at børnene peger fingre, kvinderne går i en stor bue uden om ham, og mændene smiler ad ham

Med stor pinagtighed er han nået halvvejs ned ad gågaden, da han standses af en hund der knurrer vredt ad ham. Han løfter benet for at tage et skridt og hunden er på nippet til at springe på hàm. Hundens ejer betragter anerkendende episoden, tilfreds over at hans vagtdyr har instinkterne i orden. Til sidst trækker han den med sig, efter at have klappet den beroligende.

Han bliver stående i sin stivnede stilling. Mennesker iler eller slentrer forbi under og ved siden af ham. En dreng river sig løs fra sin mor, løber hen mod ham.

- Se, er det en reklame? råber han begejstret.

- Pas på, du må ikke røre ved den, svarer den forskrækkede mor og trækker ham væk." (Op.cit. p. 67)

10. Det er nok vigtigt at fastholde, at Tugt og utugt $i$ mellemtiden henviser til fx. Balzacs Paris med by-beskrivelsens veksleride og vandrende optikker, men også til en modernisering af byen, der sker gennem det tyvende århundrede og som måske især er tydelig i mindre byer: en ordning af vækst og ro i veldefinerede zoner, en parcellering af den bymæssige praksis, helt anderledes end forrige århundredes bymæssige kvarterer.

11. Distinktionen mellem place og space genfinder man i Michel de Certeaus skelnen mellem lieu og espace i „Practiques. d'espace”, in: 
L'invention du quotidien (1980: Bd. 1, Arts de faire). De to rumlige funktioner er hhv. et stabilt, dimensioneret rum (lieu) og et.rum skabt af rumlig praksis (espace). 'Rummet' i de Certeaus betydning har flere fællestræk med såvel byplans-arkitekternes begreber om place og space som med Jan Kjærstads bestemmelse af et sted ved dets genius loci eller virtuelle, narrative mønsterdannelser. de Certeau lader sine analyser af hverdagslig rumlig praksis, fx. at gå i en by eller at beskrive sin lejlighed, munde i analyser af rummet som en narrativ praksis, som viser at lieu og espace (på samme måde som en vandring gennem byen og byens plan) er simultant eksisterende og at denne simultaneitet er stedets system. Den byplan-teoretiske distinktion mellem place og space er da heller ikke eksklusiv, selvom der fx. i et historisk perspektiv opereres med en overgang fra place til space. Med udgangspunkt i diskussioner af Harvey Cox' The Secular City (1965) skriver Charles Jenks i Modern Movements in Architecture: "For in The Secular City Debate (1966), the point became clear that the Secular City was like its father the Orgman ["the organization man". $\mathrm{mph}$, an ideal-type that never really quite existed in fact but whose presence was always just imminent. That is, this debate pointed out how even in the most advanced technopolis there still exist a majority of systems which are pre-urban and personalized, either because they have continued from the past or because they have a tendency to crystallize in the present [...]" (Jenks 1985, p. 329)

12. Jvf. Stephan Oetterman: Das Panorama. Die Geschichte eines Massenmediums. Frankfurt a.M. 1980.

13. Madsen 1976, bd. 2, pp. 292

14. „Instead of the inconvenience of filth and confusion, we have now got the boredom of hygiene. The material slum has gone-in Holland for example it has - but what has replaced it? Just mile upon mile of organized nowhere, and nobody feeling he is 'somebody living somewhere'." (Team Ten Primer, ed. Alison Smithson, London 1965, p. 43. Her citeret efter Jenks 1985, p. 311. Den danske oversættelse er min).

15. „By the end of the fifties, sociologists had fixed the outlines of Orgman. He was, as one might guess; basically nondescript, but in as far as he had an character it was 'other directed' rather than 'inner directed'; that is made up of socially conditioned drives rather than personally created goals.[...] the life of urban man. was becoming more anonymous and mobile; or in architectural terms there was an inexorable movement from symbolically rich systems to impoverished ones, from cultural roles to functional ones, or just simply from place to space." (Jenks 1985, pp. 301 og 302. Den danske oversættelse er min)

16. Citeret efter udstillingskatalogen Bybilledet, 1982, pp. 68.

\section{Litteratur}

Svend Åge Madsen: Tugt og utugt i mellemtiden, Kbh. 1976

Svend Åge Madsen: At fortælle menneskene, Kbh. 1989

Svend Åge Madsen: Syv aldres galskab, Kbh. 1994

Charles Jenks: Modern Movements in Architecture, 2. ed., Penguin 1985 Jan Kjærstad: Homo Falsus, Oslo 1984

Jan Kjærstad: Menneskets matrise. Litteratur i 80-årene. Oslo 1989 Jan Kjærstad: Rand, Oslo 1990

"Jan Kjærstad: „Menneskets felt”, in: Kritik 111, Kbh. 1995

Leon Krier: "Rekonstruktion af byen“, in: Bybilledet, ed. Stig Brøgger Kbh. 1982 